\title{
ANTIOXIDANT ACTIVITY OF Agaricus brasiliensis BASIDIOCARPS ON DIFFERENT MATURATION PHASES
}

\author{
Francielly Mourão, Suzana Harue Umeo, Orlando Seiko Takemura, Giani Andrea Linde, Nelson Barros Colauto*
}

Universidade Paranaense, Campus I de Umuarama, Laboratório de Biologia Molecular, Umuarama, PR, Brasil.

Submitted: November 13, 2009; Approved: August 23, 2010.

\begin{abstract}
Different maturation phases of basidiocarp could affect the bioactivity and concentration of some active substances. A. brasiliensis Wasser et al. (A. blazei Murrill) has shown antitumor activity that could be related to the antioxidant activity. However there is no information of the best basidiocarp maturation phase for extracting antioxidant substances in order to determine the moment of harvesting in mushroom cultivation. The objective of this work was to evaluate the antioxidant activity of A. brasiliensis strains on different basidiocarp maturation phases. The best condition for extraction of A. brasiliensis antioxidants is with methanol as solvent at $60{ }^{\circ} \mathrm{C}$ for $60 \mathrm{~min}$. Strains with closed basidiocarp have higher antioxidant activity than with opened basidiocarp. Antioxidant activity varies in each strain. It was concluded that A. brasiliensis is a natural source of antioxidant compounds. Also there is higher antioxidant activity in closed than opened caps and consequently higher functional activity. It reinforces the synergic action among different A. brasiliensis compounds as a functional food and the importance of further investigation for isolation and characterization of antioxidant substances of A. brasiliensis. It also determines the best harvest period in order to obtain the highest antioxidant activity from basidiocarp.
\end{abstract}

Key words: absorbance, antioxidant activity, basidiomycete, Agaricus blazei, DPPH.

\section{INTRODUCTION}

Oxidants are natural products of aerobic metabolism that can be produced at elevated rates under pathophysiological conditions (27). It is a paradox that the vast majority of complex organisms on Earth require oxygen for their existence when oxygen is a highly reactive molecule that damages by producing reactive oxygen species in the living organism cells. In order to compensate it cell metabolism produces antioxidant compounds to stabilize the oxidative processes as a healthprotecting factor. However depending on pathological condition it is recommended a diet with antioxidant compounds to reduce the risk of chronic diseases (1). Agaricus brasiliensis Wasser et al. (A. blazei Murrill ss. Heinemann) (31) is a basidiomycete used as a functional food with antitumoral (23), imunomudulatory (21), antidiabetic (20), antimicrobial (4), antimutagenic (28) and antioxidant (19) properties. $A$. brasiliensis composites may act alone or synergically with $\beta$ -

*Corresponding Author. Mailing address: Universidade Paranaense - Campus I, Laboratório de Biologia Molecular, Praça Mascarenhas de Moraes, 4282 - CP 224, CEP 87.502-050, Umuarama-PR-Brazil.; Tel.: +55 4436212837 Fax: +55 44 36212830; E-mail: nbc@unipar.br

Mourão, F. et al.

Antioxidant activity of $A$. brasiliensis 
D-glucans (7, 25), ergosterol (15), and/or lipids (29).

A. brasiliensis has absence of universal veil but presence of inner veil which differentiate two distinct basidiocarp maturation phases. Before the rupture of the inner veil the basidiocarp is immature and spores are in development. At this stage the basidiocarp is referred as "closed cap". After the rupture of the inner veil the basidiocarp is mature and spores are developed and ready to be spread. At that phase the basidiocarp is referred as "opened cap" (23). For commercial purposes basidiocarps are harvested before the rupture of the veil (closed cap) mainly due to sensory characteristics and firmness what makes cropping easier and reduces fragmentation during the processing in Brazil (5). Opened caps are considered visually less attractive to consumers because of released dark spores which give a dirty appearance to mushrooms. Other commercial claim in Brazil is that closed caps have a better biological activity than opened caps so they get a higher price even when the final purpose is to make capsules (23). However Camelini et al. (7) and Firenzuoli et al. (13) suggested that opened caps are likely to have better biological activity because they have higher concentration and diversity of glucans and proteins. On the other hand Bellini et al. (3) reported better results for closed cap of A. blazei and Mourão et al. (23) reported no difference between opened and closed caps with tests in vivo however they suggest that there is a tendency of better results with closed caps. The main characteristic of an antioxidant is its ability to trap free radicals. It is suggested that the antioxidants are the main factors in reducing the incidence of diseases (19). Thus the objective of this work was to evaluate the antioxidant activity of A. brasiliensis strains on different basidiocarp maturation phases.

\section{MATERIALS AND METHODS}

The experiment of antioxidant activity was carried out in the Laboratory of Molecular Biology of the Universidade Paranaense - Campus I (Sede) Umuarama. The mushroom production was carried out in the Department of Plant Production, Faculty of Agronomic Sciences, Universidade Estadual Paulista - Campus Botucatu.

The A. brasiliensis strains ABL99/26, ABL99/27, ABL99/28, ABL99/29 and ABL99/30 (coded as 26, 27, 28, 29 and 30 , respectively) were maintained on malt-extract agar at $22{ }^{\circ} \mathrm{C}$. After that the mycelium was transferred to pre-cooked $\left(100{ }^{\circ} \mathrm{C}\right.$ for $\left.40 \mathrm{~min}\right)$ and autoclaved $\left(121{ }^{\circ} \mathrm{C}\right.$ for $\left.40 \mathrm{~min}\right)$ wheat grains with addition of $\mathrm{CaCO}_{3}(1 \%)$ and kept in the dark at 28 ${ }^{\circ} \mathrm{C}$ in order to be used as inoculum (9).

The raw material used for composting was sugarcane bagasse $(500 \mathrm{~kg})$, Brachiaria $\mathrm{sp}(800 \mathrm{~kg})$ grass, coast cross grass $(2200 \mathrm{~kg})$, defatted soybean bran $(140 \mathrm{~kg})$, urea $(50 \mathrm{~kg})$, ammonium sulfate $(50 \mathrm{~kg})$ and gypsum $(30 \mathrm{~kg})$, followed by pasteurization and conditioning according to Colauto et al. (10) and Eira et al. (12). $80 \mathrm{~kg}$ of inoculated substratum with each strain was transferred to cultivation plastic boxes. Mycelial colonization of substratum was carried out in the dark for 30 days at $25{ }^{\circ} \mathrm{C} \pm 2{ }^{\circ} \mathrm{C}$ with $90 \% \pm 8 \%$ of relative humidity. Casing layer was compounded of a mixture of subsoil and charcoal $(7: 3)$ saturated with water, $\mathrm{pH}$ adjusted to 7.0 with $\mathrm{CaCO}_{3}$, pasteurized $\left(60{ }^{\circ} \mathrm{C}\right.$ for $\left.6 \mathrm{~h}\right)$ and then, after cooling, added on mycelial colonized substratum. Mushrooms were harvested separately with closed and opened caps, washed, dehydrated $\left(60{ }^{\circ} \mathrm{C}\right.$ for $\left.24 \mathrm{~h}\right)$, grounded and stored at $-70{ }^{\circ} \mathrm{C}$. In this experiment opened cap (O) was defined as a mature basidiocarp with veil completely torn apart and closed cap (C) as an immature basidiocarp with veil without damage, in one piece.

For determining mushroom extraction conditions it was used only closed caps from ABL99/30, coded as C30. Methanol, ethanol, dimethyl sulfoxide (DMSO) and water solvents were tested for timing (15, 30, 45 and $60 \mathrm{~min})$ and temperature $\left(15,30,45\right.$ and $\left.60{ }^{\circ} \mathrm{C}\right)$ of extraction. Mushroom raw extract was prepared with $1 \mathrm{~g}$ of dried and grounded basidiocarp, homogenized with $5 \mathrm{~mL}$ of solvent and kept in the 
previous times and temperatures referred. Subsequent to that each mixture was cooled in ice bath and centrifuged at $4400 \mathrm{~g}$ $\left(5{ }^{\circ} \mathrm{C}\right.$ for $\left.5 \mathrm{~min}\right)$. Supernatant was considered the raw extract and used for antioxidant activity determination. The best extraction condition (solvent $\mathrm{x}$ time $\mathrm{x}$ temperature) was used to prepare the raw extract for antioxidant activity determination in four different strains of opened and closed caps of $A$. brasiliensis. Each strain was coded for closed (C26, C27, C28 and $\mathrm{C} 29)$ and opened (O26, O27, O28 and O29) caps.

The free radical scavenging activity was determined by the 1,1-diphenyl-2-picrylhydrazyl (DPPH) method and it was used $0.1 \mathrm{ml}$ of the raw extract mixed with $2.9 \mathrm{~mL}$ of a fresh DPPH methanolic solution $(60 \mu \mathrm{M})$. After $30 \mathrm{~min}$ the decreasing value of absorbance at $515 \mathrm{~nm}$ was observed. All tests were repeated ten times. The overall antioxidant capacity was calculated using a standard solution of the reactant quercetin $(60 \mu \mathrm{M})$ as reference of $100 \%$ (22). Afterwards results were analyzed by variance analyses and the differences among averages determined by Tukey's test $(p<0.05)$.

\section{RESULTS AND DISCUSSION}

Methanol was the best solvent for extraction of antioxidants $(p<0.05$; Table 1$)$. It can be associated to small molecular size and the affinity with both polar and non-polar compounds (2) making an easy interaction with cell membranes associated with high chemical affinity with lipids, ergosterol and $\beta$-D-glucans. Different biological activities, including antioxidant activities, are reported for ergosterol (24) and $\beta$-D-glucans (6).

Table 1. Effect of extraction conditions on antioxidant activity of closed cap A. brasiliensis ABL99/30 (C30) strain

\begin{tabular}{lccc}
\hline Solvent (1:5) & Time $(\mathbf{m i n})$ & Temperature $\left({ }^{\mathbf{0}} \mathbf{C}\right)$ & Antioxidant activity $(\boldsymbol{\%}){ }^{*}$ \\
\hline Dimethyl sulfoxide & 60 & 60 & 0.00 \\
Ethanol & 60 & 60 & $59.03 \mathrm{~b}$ \\
Methanol & 60 & 60 & $81.20 \mathrm{a}$ \\
Water & 60 & 60 & 0.00 \\
\hline Methanol & 60 & 15 & $14.36 \delta$ \\
Methanol & 60 & 30 & $18.54 \gamma$ \\
Methanol & 60 & 45 & $30.00 \beta$ \\
Methanol & 60 & 60 & $81.43 \alpha$ \\
\hline Methanol & 15 & 60 & $64.28 \mathrm{C}$ \\
Methanol & 30 & 60 & $76.67 \mathrm{~B}$ \\
Methanol & 45 & 60 & $80.58 \mathrm{~A}$ \\
Methanol & 60 & 60 & $81.09 \mathrm{~A}$ \\
\hline
\end{tabular}

*Means followed by different letters indicate significant differences among the groups according to Tukey's test ( $p<0.05)$.

The best temperature of antioxidant extraction $(p<0.05)$ was at $60{ }^{\circ} \mathrm{C}$ (Table 1). Higher temperatures improved the antioxidant extraction process although it could break down molecules by the excess of energy. Temperatures higher than
$65{ }^{\circ} \mathrm{C}$ showed to be inefficient to the extraction of antioxidants mainly because they were higher than melting point of methanol (data not shown). It is possible that better results could be achieved with a pressurized system or supercritical 
solvent. Thus it is important to determine the ideal temperature extraction to keep the integrity of the antioxidant compounds associated with the high bioactivity extraction capacity of antioxidants. In this work the observed $60{ }^{\circ} \mathrm{C}$ of antioxidant activity extraction demonstrate that there is a good stability of A. brasiliensis antioxidant molecules.

There were no differences $(p<0.05)$ between 45 and 60 min for the extraction time of antioxidants (Table 1) nevertheless at $60 \mathrm{~min}$ the standard deviation was lower. It suggests that higher time extraction for solvent action is important in order to promote an efficient and reproducible extraction of antioxidants for this fungus.

Methanolic extracts showed different antioxidant activities between basidiocarp maturation phases and strains (Figure 1).
Antioxidant activity was found in higher quantity on closed than opened caps for all strains. The average antioxidant activity for the closed cap group was $24 \%$ higher than opened caps. As the mushroom were produced in the same cultivation conditions these results reinforces that difference is directly related to mushroom maturation phase for each strain. For the same reason the strain variation of scavenging activity occurred due to genetic diversity. Also the choice of harvesting mushrooms before or just after the veil rupture is critical for obtaining higher quantities of antioxidant and possibly antitumor activity, maximizing profit on mushroom cultivation with better quality of active principles. Also it shows that closed than opened caps are a better protective agent for reducing oxidative damages of free radicals.

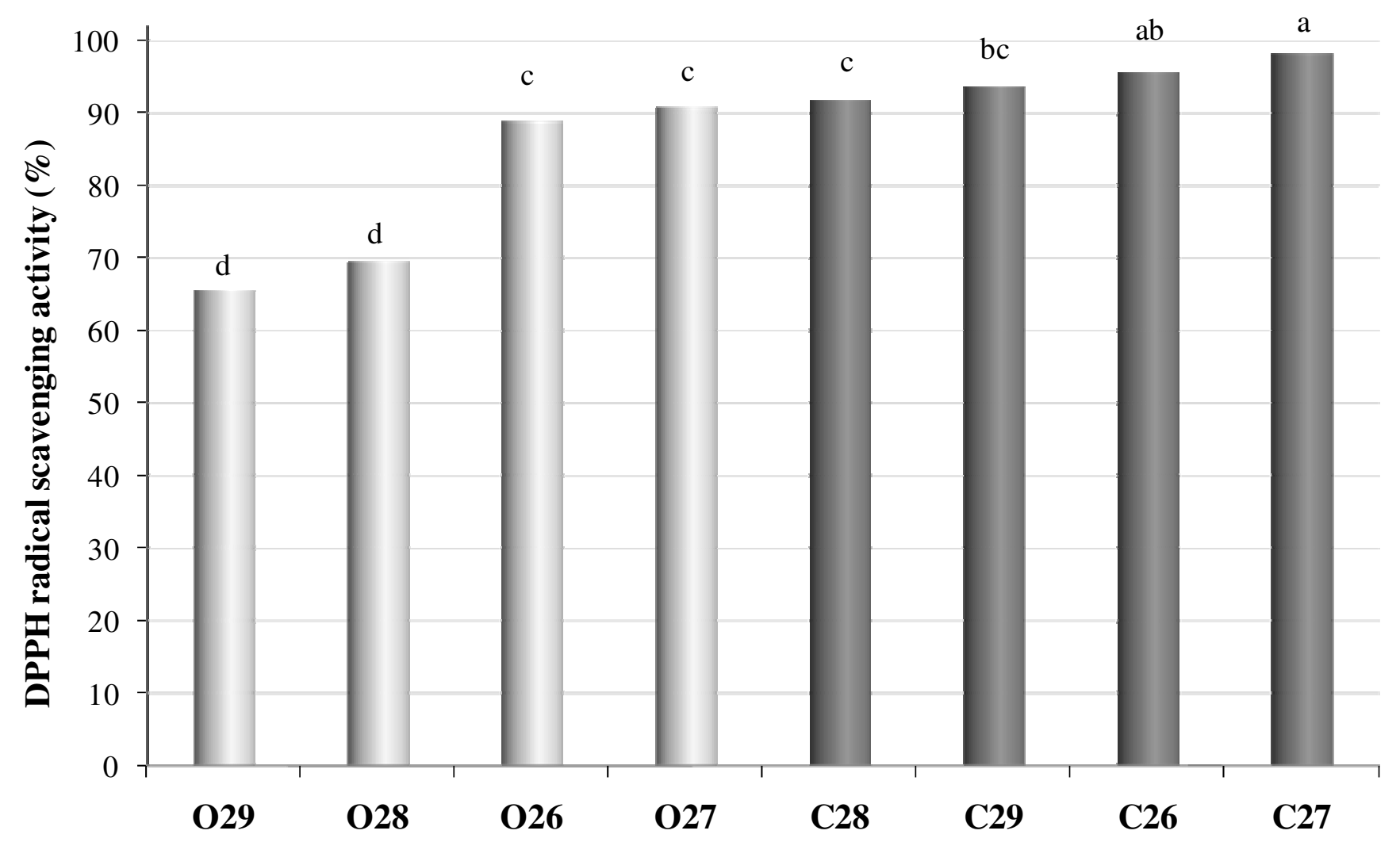

Figure 1. Antioxidant activity of closed (C) and opened (O) caps of ABL99/26 (26), ABL99/27 (27), ABL99/28 (28) and ABL99/29 (29) A. brasiliensis strains. Means followed by different letters indicate differences according to Tukey's test ( $p<0.05)$. 
$\beta$-D-glucans are the main responsible for biological activity of $A$. blazei (18). The $\beta$-D-glucan structure is (1-6)- $\beta$ backbone with (1-3)- $\beta$ side branches in the ratio of 1:2 (26). While linear (1-6)- $\beta$-glucan seems to be inactive (18) (1-3)- $\beta$ side branches have been considered with biochemical importance mainly in antitumor activity (11). Camelini et al. (7) reported that the amount of (1-3)- $\beta$-glucans and polysaccharide-protein complexes increase as fruiting bodies mature. Based on it Camelini et al. (7) suggested opened than closed caps for using as functional foods. However Bellini et al. (3) reported that closed cap extracts were much more efficient for reduction of DNA damages and Mourão et al. (23) suggested that there is a tendency of better effects of closed than opened caps for Sarcoma 180 tumor inhibition. In spite of chemical structure indicates a better bioactivity on opened than closed caps of $A$. brasiliensis extracts (7), in our experiment, closed than opened cap extracts showed better results.

Chye et al. (8) determined important antioxidant compounds on edible wild mushrooms. Izawa and Inoue (17) suggested that A. blazei extracts contain a complex mixture of antioxidants and other substances that may act synergically for reducing free radicals. Huang and Mau (16) reported naturally antioxidant composites in methanolic extracts of A. blazei such as ascorbic acid, $\alpha$-tocopherols and total phenols. Halliwell et al. (14) reported that mannitol, histidine and adenosine monophosphate showed scavenging capacity on hydroxyl radicals and Tsai et al. (30) described the contents of mannitol, histidine and adenosine monophosphate in A. blazei. A lipid fraction of A. blazei have been shown antitumor activity against solid tumors in which ergosterol was responsible for this activity (29). Apparently the presence of all those referred compounds in A. brasiliensis extracts could have synergic antioxidant activity as an alternative for $\beta$-glucans and possibly antitumor activities.

Furthermore Ker et al. (19) associated the potent antioxidant effect of $A$. blazei with low content of polysaccharide-protein complexes, which according to
Camelini et al. (7) is found in closed than opened basidiocarp. It associated with other synergic compounds could explain the higher free radical scavenging capacity of closed caps reported in this work. It reinforces the synergic action among different A. brasiliensis compounds and the importance of further investigation for isolation and characterization of antioxidant substances of $A$. brasiliensis.

In conclusion A. brasiliensis is a natural source of antioxidant compounds. The best condition for extraction of antioxidants is with methanol as solvent at $60{ }^{\circ} \mathrm{C}$ for $60 \mathrm{~min}$. Also there is higher antioxidant activity in closed than opened caps.

\section{ACKNOWLEDGMENTS}

The authors thank Universidade Paranaense, Universidade Estadual Paulista, Fundação Araucária and CNPq for financial support and Professor Augusto F. da Eira for the A. brasiliensis strains.

\section{REFERENCES}

1. Ames, B.N. (1983). Dietary carcinogens and anticarcinogens. Oxygen radicals and degenerative diseases. Science 221 (4617), 1256-1264.

2. Badolato, E.S.G.; Duran, M.C. (2000). Risco de intoxicação por metanol pela ingestão de bebidas alcoólicas. Rev. Psiquiatr. Clin. 27 (2), 90-92.

3. Bellini, M.F.; Giacomini, N.; Eira, A.F.; Ribeiro, L.R. and Mantovani, M.S. (2003). Anticlastogenic effect of aqueous extracts of Agaricus blazei on CHO-k1 cells, studying different developmental phases of the mushroom. Toxicol. In Vitro 17 (4), 465-469.

4. Bernardshaw, S.; Johnson, E.; Hetland, G. (2005). An extract of the mushroom Agaricus blazei Murill administered orally protects against systemic Streptococcus pneumoniae infection in mice. Scand. J. Immunol. 62 (4), 393-398.

5. Braga, G.C.; Eira, A.F.; Celso, P.G.; Colauto, N.B. (1998). Manual do Cultivo de $\underline{\text { Agaricus }} \underline{\text { blazei }}$ Murril "Cogumelo-do-sol". FEPAF, Botucatu.

6. Brown, G.D.; Gordon, S. (2001). A new receptor for $\beta$-glucans. Nature 413, 36-37.

7. Camelini, C.M.; Maraschin, M.; Mendonça, M.M.; Zucco, C.; Ferreira, A.G.; Tavares, L.A. (2005). Structural characterization of $\beta$-glucans of 
Agaricus brasiliensis in different stages of fruiting body maturity and their use in nutraceutical products. Biotechnol. Lett. 27 (17), 1295-1299.

8. Chye, F.Y.; Wong, J.Y.; Lee, J.S. (2008). Nutritional quality and antioxidant activity of selected edible wild mushrooms. Food Sci. Technol. Res. 14 (4), 375-384.

9. Colauto, N.B.; Aizono, P.M.; Carvalho, L.R.M.; Paccola-Meirelles, L.D.; Linde, G.A. (2008). Temperature and $\mathrm{pH}$ conditions for mycelial growth of Agaricus brasiliensis on axenic cultivation. Semina: Cienc. Agrar. 29 (2), 307-312.

10. Colauto, N.B.; Silveira, A.R.; Eira, A.F.; Linde, G.A. (2010). Alternative to peat for Agaricus brasiliensis yield. Bioresour. Technol. 101 (2), 712 716.

11. Dong, Q.; Yao, J.; Yang, X.T.; Fang, J.N. (2002). Structural characterization of a water-soluble $\beta$-D-glucan from fruiting bodies of Agaricus blazei Murr. Carbohydr. Res. 337 (15), 1417-1421.

12. Eira, A.F.; Nascimento, J.S.; Colauto, N.B.; Celso, P.G. (2005). Tecnologia de cultivo do cogumelo medicinal Agaricus blazei (Agaricus brasiliensis). Agropec. Catarin. 18 (3), 45-49.

13. Firenzuoli, F.; Gori, L.; Lombardo, G. (2008). The medicinal mushroom Agaricus blazei Murrill: review of literature and pharmaco-toxicological problems. Evid. Based Complement. Alternat. Med. 5 (1), 3-15.

14. Halliwell, B.; Gutteridge, J.M.C.; Aruoma, O.I. (1987). The deoxyribose method: a simple "test-tube" assay for determination of rate constants for reactions of hydroxyl radicals. Anal. Biochem. 165 (1), 215-219.

15. Hirotani, M.; Sai, K.; Hirotani, S.; Yoshikawa, T. (2002). Blazeispirols B, C, E and F, des-A-ergostane-type compounds, from the cultured mycelia of the fungus Agaricus blazei. Phytochemistry 59 (55), 571-577.

16. Huang, S.J.; Mau, J.L. (2006). Antioxidant properties of methanolic extracts from Agaricus blazei with various doses of $\gamma$-irradiation. Lebensm. Wiss. Technol. 39 (7), 707-716.

17. Izawa, S.; Inoue, Y.A. (2004). A screening system for antioxidants using thioredoxin-deficient yeast: discovery of thermostable antioxidant activity from Agaricus blazei Murill. Appl. Microbiol. Biotechnol. 64 (4), 537-542.

18. Jong, S.C. (2002). Fungal cell wall glycans. In: Vandamme, E.J.; De Baets, S.; Steinbüchel, A. (eds). Biopolymers: Polysaccharides II: Polysaccharides from Eukaryotes. Wiley-VCH, Weinheim, p. 159-178.

19. Ker, Y.B.; Chen, K.C.; Chyau, C.C.; Chen, C.C.; Guo, J.H.; Hsieh, C.L.; Wang, H.E.; Peng, C.C.; Chang, C.H.; Peng, R.Y. (2005). Antioxidant capability of polysaccharides fractionated from submerge-cultured Agaricus blazei mycelia. J. Agric. Food. Chem. 53 (18), 7052-7058.

20. Kim, Y.W.; Kim, K.H.; Choi, H.J.; Lee, D.S. (2005). Anti-diabetic activity of $\beta$-glucans and their enzymatically hydrolyzed oligosaccharides from Agaricus blazei. Biotechnol. Lett. 27 (77), 483487.

21. Liu, Y.; Fukuwatari, Y.; Okumura, K.; Takeda, K.; Ishibashi, K.I.; Furukawa, M.; Ohno, N.; Mori, K.; Gao, M.; Motoi, M. (2007). Immunomodulating activity of Agaricus brasiliensis KA21 in mice and in human volunteers. Evid. Based Complement. Alternat. Med. 5 (2), 205-219.

22. Molyneux, P. (2004). The use of the stable free radical diphenylpicrylhydrazyl (DPPH) for estimating antioxidant activity. Songklanakarin J. Sci. Technol. 26 (2), 211-219.

23. Mourão, F.; Linde, G.A.; Messa, V.; Cunha Jr., P.L.; Silva, A.V.; Eira, A.F.; Colauto, N.B. (2009). Antineoplasic activity of Agaricus brasiliensis basidiocarps on different maturation phases. Braz. J. Microbiol. 40 (4), 901-905.

24. Nylund, J.E.; Wallander, H. (1992). Ergosterol analysis as a means of quantifying mycorrhizal biomass. In: Norris, J.R.; Read, D.J.; Varma, A.K. (eds). Methods in Microbiology. Academic Press, London, p. $77-$ 88.

25. Ohno, N.; Hayashi, M.; Iino, K.; Suzuki, I.; Oikawa, S.; Sato, K.; Suzuki, Y.; Yadomae, T. (1986). Effect of glucans on the antitumor activity of Grifolan. Chem. Pharm. Bull. 34 (5), 2149-2154.

26. Ohno, N.; Furukawa, M.; Miura, N.N.; Adachi, Y.; Motoi, M.; Yadomae, T. (2001). Antitumor $\beta$-glucan from the cultured fruit body of Agaricus blazei. Biol. Pharm. Bull. 24 (7820), 820-828.

27. Sies, H. (1993). Strategies of antioxidant defense. Eur. J. Biochem. 215 (2), 213-219.

28. Souza-Paccola, E.A.; Bomfeti, C.A.; Fávaro, L.C.L.; Fonseca, I.C.B.; Paccola-Meirelles, L.D. (2004). Antimutagenic action of Lentinula edodes and Agaricus blazei on Aspergillus nidulans conidia. Braz. J. Microbiol. 35 (4), 311-315.

29. Takaku, T.; Kimura, Y.; Okuda, H. (2001). Isolation of an antitumor compound from Agaricus blazei Murill and its mechanism of action. J. Nutr. 131 (2), 1409-1413.

30. Tsai, S.; Tsai, H.; Mau, J. (2007). Antioxidant properties of Agaricus blazei, Agrocybe cylindracea and Boletus edulis. Lebensm. Wiss. Technol. 40 (8), 1392-1402.

31. Wasser, S.P.; Diduk, M.Y.; Amazonas, M.A.L.A.; Nevo, E.; Stamets, P.; Eira, A.F. (2002). Is a widely cultivated culinary-medicinal royal sun Agaricus (the himematsutake mushroom) indeed Agaricus blazei Murril? Int. J. Med. Mushrooms 4 (4), 267-290. 